\title{
Sønderjyske Årbøger 1889-2014
}

Af Hans SChultz Hansen

Blandt de mange jubilæer, som markeres i 2014 - 200-året for Norges selvstændighed, 150-året for Anden slesvigske Krig, 100-året for Første Verdenskrigs udbrud - kan 125-året for første årgang af Sønderjyske Årbøger i 1889 forekomme beskedent. I Historisk Samfund for Sønderjylland hverken kan eller skal det forbigås i tavshed. Det fejres derfor med denne særligt omfangsrige årgang 2014 af det hæderkronede tidsskrift, ligesom det skete ved de tidligere jubilæer i 1964 og 1989. Årgangen rummer desuden en samlet indholdsfortegnelse til årgangene 2000-2014 ved Hans-Ole Mørk, som viderefører tidligere indholdsfortegnelser fra 1989 og 1999. ${ }^{1}$

Sønderjyske Årbøger blev grundlagt som et dansk tidsskrift i forbindelse med nationalitetskampen under det preussiske herredømme over Sønderjylland. ${ }^{2}$ De tre første redaktører havde alle en fremtrædende placering i tidens danske bevægelse. Det var H.P. HanssenNørremølle, dengang sekretær i Vælgerforeningen for Nordslesvig og danskhedens utrættelige organisator, Gustav Johannsen, sønderjydernes repræsentant i rigsdagen og landdagen i Berlin, og Peter Skau, gårdejer på Bukshave i Fjelstrup sogn med talrige hverv som medlem af bl.a. provinslanddag, kredsdag og provstisynode. Initiativet til Sønderjyske Årbøger blev imidlertid taget i København af rigsarkivar A.D. Jørgensen, der var født og opvokset i Gråsten og levende optaget af sin hjemstavns historie. Sammen med lærer Peter Lauridsen, der kom fra Jegerup ved Vojens og siden blev kendt som forfatter af ottebindsværket $D a$ Sønderjylland vaagnede, fungerede han som en kongerigsk støttegruppe for redaktionen. De drivende kræfter i de første år var uden tvivl A.D. Jørgensen og H.P. Hanssen.

Indtil 1914 var Sønderjyske Årbøger både et historisk og et aktuelt tidsskrift. Artiklerne om sønderjysk historie var i hovedsagen skrevet af kongerigske historikere, gerne med sønderjyske rødder, mens de aktuelle var skrevet af fremtrædende mænd fra landsdelens danske bevægelse.

Sønderjyske Årbøger undgik ikke konflikt med de preussiske myndigheder, som i april 1896 anklagede H.P. Hanssen for at begå »grober Unfug « ved at benytte navnet »Sønderjylland « og tillægsordet »søn- 
derjysk «. I april 1897 blev H.P. Hanssen frikendt ved domstolene, men da var et år gået, hvorfor årgang 1896 blev sprunget over. Årgang 1898 led samme skæbne pga. A.D. Jørgensens død i 1897 og nogle praktiske vanskeligheder. Sidstnævnte forhindrede også årgang 1911. Derefter udkom årgangene 1912 og 1913 og første hæfte af 1914, mens andet hæfte af 1914 blev forhindret af militærcensuren under Første Verdenskrig og siden af to brande i trykkeriet og derfor først udkom i 1923. Årgangene 1915-22 udkom aldrig på grund af krigen og den efterfølgende grænsekamp.

I december 1922 blev Historisk Samfund for Sønderjylland stiftet, og videreførelsen af Sønderjyske Årbøger blev fra begyndelsen en hovedopgave for den nye forening - og sådan har det været siden. Det er således lykkedes Historisk Samfund at undgå flere huller i rækken. De vægtige grunde, som var skyld i de førnævnte manglende årgange, har i så henseende lagt - og lægger stadig - et moralsk pres på den til enhver tid værende redaktion. Årgang 1932 udgøres dog af Festskrift til H.P. Hanssen paa hans 70 Aars Dag den 21. Februar 1932, der udkom i et større format og omfang end det normale og derved falder lidt udenfor. Fra 1922 blev Sønderjyske Årbøger i første række et historisk tidsskrift med bidrag om landsdelens regionale og lokale historie.

Om årbøgernes historie med Historisk Samfund som udgiver kan man læse i Inge Adriansen og Henrik Fangels store artikel om lokalhistorisk arbejde i Sønderjylland 1889-1989 i 1989-årgangen. Her skal blot tilføjes nogle oplysninger om årbogens udvikling i de sidste 25 år.

Årgangene 1990 og 1991 blev redigeret af rektor Knud Fanø og arkivar Lars N. Henningsen. Fra 1992 og til og med 2002 var Henningsen eneredaktør, sideløbende med at han varetog formandshvervet $\mathrm{i}$ foreningen. Fra 2003 til nu har årbogen til gengæld haft en talstærk redaktion, hvor følgende har medvirket i kortere eller længere tid, her nævnt i kronologisk orden: Axel Johnsen, Tina Sahl Lydiksen, Jesper Bolund Nielsen, René Rasmussen, Andrea Graw-Teebken, Hans-Ole Mørk, Harald Wolbersen, Morten Andersen, Mikkel Leth Jespersen, Mogens Rostgaard Nissen, Anne Marie Overgaard, Hans Schultz Hansen og Mads Mikkel Tørsleff.

Årbogens ydre har vekslet en del i de sidste 25 år. I 1992 forlod man det mørkerøde lærredsbind med smudsomslag til fordel for et omslag med for- og bagsideillustrationer i farver, som indgik i bindet. 
Fra 2005 er bagsideillustrationen erstattet af en summarisk indholdsfortegnelse. Samme år udskiftedes den faste grundfarve i omslaget af skiftende grundfarver, der hjælper til at skelne de enkelte årgange fra hinanden. Også i årbøgernes indre satte farver sig igennem i stadig flere illustrationer. Indholdsmæssigt ligner de seneste 25 årgange hinanden med et tilstræbt mix af historiefaglige artikler og erindringer. Det har ikke været tilsigtet at samle artikelstoffet om bestemte temaer, men i nogle årgange har der været en tættere forbindelse mellem flere af artiklerne, f.eks. i årgang 2013 og 2014, der præges af jubilæerne for 1864 og 1914. I særdeleshed gælder det for årgang 1995, der udkom fyldigere end normalt med adskillige artikler med relation til 75-året for Genforeningen i 1920, med to erindringer fra Historisk Samfunds erindringskonkurrence i samme anledning og med taler fra årets afstemnings- og genforeningsfester.

Ud over artikler og erindringer og anmeldelser af nye bøger rummer Sønderjyske Årbøger traditionelt et omfattende beretningsstof fra landsdelens arkiver, biblioteker, museer og forskningsinstitutioner. Skiftende redaktører har i årenes løb forsøgt at begrænse disse beretninger, som ingen ønsker at undvære, men som heller ikke må optage for megen plads.

Som årtierne er gået, og interessen for den sønderjyske historie uden for landsdelen selv er blevet mindre, er forfatterkredsen i stigende grad blevet sammensat af folk fra områdets arkiver, biblioteker, museer og forskningsinstitutioner, hvortil kommer ikke så få studerende. Den udgøres stadig af en passende blanding af professionelle forskere, amatørforskere og erindringsskrivere. Det har ikke afgørende ændret på denne sammensætning, at årbogen i 2008 indførte fagfællebedømmelser af de historiefaglige artikler. De foregår under medvirken af anonyme bedømmere på forskerniveau uden for redaktionens kreds. De er en nødvendighed for, at Sønderjyske Årbøger kan opretholde sin status som det førende danske videnskabelige tidsskrift inden for forskningsområdet Sønderjyllands historie. Fra 2010 er årbogens artikler desuden blevet forsynet med et resumé på tysk. Hensigten hermed har været, at danske forskningsresultater og synsvinkler på den sønderjyske historie lettere kan nyttiggøres for tysk historieskrivning.

Ved siden af denne professionalisering i det ydre og det indre har de skiftende redaktioner bestræbt sig på, at Sønderjyske Årbøger samtidig fremstår som et folkeligt tidsskrift, hvor såvel de enkelte artikler 
som helheden mest muligt tiltaler den almindeligt historisk interesserede læser. Kun ved at forblive i denne tradition, der har præget årbogen siden dens første årgang, kan årbogen for alvor yde sit bidrag til virkeliggørelsen af Historisk Samfund for Sønderjyllands formålsparagraf: »at fremme interessen og forståelsen for Sønderjyllands historie«.

\section{NOTER}

1. Niels H. Kragh-Nielsen: »Artikler og anmeldelser «, Børge L. Barløse: Register til Sønderjyske Ärbøger 1889-1988. Aabenraa 1989, s. 391-487. Niels H. Kragh-Nielsen: "Indholdsfortegnelse 1989-99", Sønderjyske Årbøger 1999 , s. 317-345.

2. Sønderjyske Årbøgers historie er tidligere skildret hos H. Lausten-Thomsen: "Sønderjydske årbøger i 50 år", Sønderjyske Arbøger 1939, s. 1-7, Peter Kr. Iversen: Nogle jubilæer«, sst.

1964, s. 1-10, og Harald Jørgensen: »Baggrunden for oprettelsen af Sønderjyske Årbøger«, sst. s. 11-26, samt Peter Kr. Iversen: »Erindringer fra redaktionsarbejdet med Sønderjyske Årbøger«, sst. 1989, s. 7-16. Årbøgernes historie er tillige beskrevet på baggrund af lokalhistorien hos Inge Adriansen og Henrik Fangel: »Lokalhistorisk arbejde i Sønderjylland 18891989«, Sønderjyske Årbøger 1989, s. 385504.
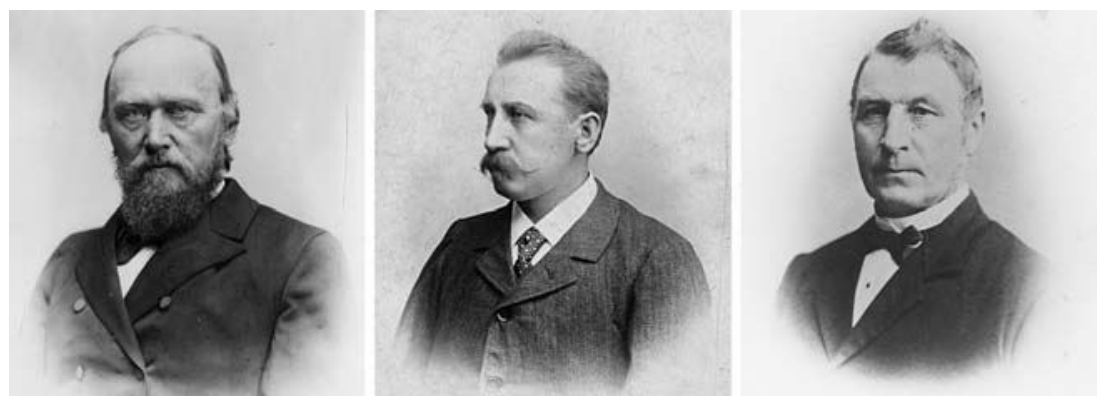

Tre af hovedpersonerne ved grundlæggelsen af Sønderjyske Årbøger: A.D. Jørgensen, H.P. Hanssen og Peter Skau. Foto: Museum Sønderjylland - ISL. 